\title{
Effect of xylanases on peroxide bleachability of eucalypt (E. globulus) kraft pulp
}

\author{
Anatoly A. Shatalov*, Helena Pereira \\ Centro de Estudos Florestais, Universidade Técnica de Lisboa, Instituto Superior de Agronomia, Tapada da Ajuda, \\ 1349-017 Lisboa, Portugal
}

Received 23 February 2007; received in revised form 12 September 2007; accepted 18 November 2007

\begin{abstract}
Industrial eucalypt (E. globulus L.) kraft pulp was treated with two commercial xylanase preparations Ecopulp ${ }^{\circledR}$ TX-200A and Pulpzyme ${ }^{\circledR}$ HC (endo-1,4- $\beta$-xylanase activity; EC 3.2.1.8) and bleached by totally chlorine-free (TCF) three-stage hydrogen peroxide bleaching sequence, without oxygen pre-delignification. The effect of enzymatic stage on pulp properties and bleachability has been studied and compared with reference (control) pulps, processed without enzyme addition. The similar mode of enzymatic action was noted for both xylanase preparations. Final brightness of $86 \%$ ISO was achieved after complete bleaching. Direct bleaching effect caused pulp brightening (by 1.2-1.5\% ISO) and delignification (by 7-10\%) immediately after the enzymatic stage. The maximal bleach boosting was shown after the first peroxide stage and then diminished, despite the progressive increase in delignification over the control. The loss in efficiency of xylanase treatment by the end of peroxide bleaching was associated with specific behavior of xylan-derived chromophores, i.e., hexenuronic acids.
\end{abstract}

(C) 2007 Elsevier B.V. All rights reserved.

Keywords: Xylanase bleaching; Eucalypt kraft pulp; Biocatalysis; Enzymes; Enzyme biocatalysis; Enzyme technology

\section{Introduction}

Biobleaching, i.e., enzymatic pulp pre-treatment (prebleaching) with xylanases (endo-1,4- $\beta$-xylanase activity, EC 3.2.1.8.) before chemical bleaching, is an alternative and cost-effective way to reduce consumption of chlorine-based bleaching chemicals in pulp mills and to minimize thereby formation of toxic chlorinated organic substances in bleach mill effluents [1,2]. Mill scale trials showed that xylanase pretreatment results in up to $20-25 \%$ savings in total active chlorine for hardwoods and $10-15 \%$ for softwoods with simultaneous decrease in AOX (adsorbable organic halides) by 12-25\% [3]. Xylanase treatment can substantially improve the final brightness of bleached pulps, along with a decrease in bleaching costs, when combined with non-chlorine bleaching chemicals (hydrogen peroxide and ozone) within TCF (totally chlorine free) bleaching sequences [4].

The role of xylanases in pulp bleaching is to enhance the effect of bleaching chemicals through the limited hydrolysis

\footnotetext{
* Corresponding author. Tel.: +35121363 4662; fax: +351213645000

E-mail address: anatoly@isa.utl.pt (A.A. Shatalov).
}

of the xylan network (bleach boosting) rather than to attack directly the lignin-based chromophores and to remove lignin [5]. The bleachability improvement of traditional alkaline pulps was suggested to be due to selective hydrolysis of reprecipitated xylan from the fibre surface and pores and therefore to improved fibre permeability, what increases the accessibility of lignin to bleaching reagents and facilitates the removal of lignin degradation products into the bulk solution $[2,6]$, or to enhanced extractability of lignin-carbohydrate complexes (LCC), what facilitates the pulp delignification during subsequent chemical bleaching steps [7]. The xylanase-assisted removal of carbohydrate-derived chromophores (such as hexenuronic acids) can also affect the pulp bleachability [8].

The short-rotation (8-12 years) intensively managed plantations of Eucalyptus globulus L. are nowadays the main source of industrial wood for production of market hardwood bleached kraft pulp in Portugal and Spain [9]. In Portugal, the E. globulus wood covers about $80 \%$ of total raw material needs for commercial kraft pulp production [10]. Despite a large body of reported data concerning different aspects of xylanase-aided ECF (elemental chlorine free) and TCF bleaching of various wood (and non-wood) species, there is a lack of information about the actual effect of xylanases during the long-term per- 
oxide bleaching directed at a target brightness of fully bleached pulps (85\% ISO and more).

The fate of xylanase bleach boosting effect during three-stage hydrogen peroxide bleaching of E. globulus kraft pulp was studied in terms of change in pulp properties and bleachability over the control after each subsequent bleaching stage. The results of this study are reported in the present paper.

\section{Materials and methods}

\subsection{Materials}

Industrial unbleached kraft pulp produced from eucalypt wood (E. globulus L.) was obtained from the Portucel mill (Setúbal, Portugal). The pulp had $41.3 \%$ ISO brightness, $3.4 \%$ of residual lignin (as Klason and acid-soluble lignin) and an intrinsic viscosity of $1348 \mathrm{ml} \mathrm{g}^{-1}$. Before bleaching, the pulp was thoroughly washed with deionized water to remove all residual black liquor.

Two commercial xylanase preparations Ecopulp ${ }^{\circledR}$ TX-200A (AB Enzymes, Germany) and Pulpzyme ${ }^{\circledR}$ HC (Novozymes A/S, Denmark) were used for bleaching experiments. Ecopulp ${ }^{\circledR}$ TX-200A is a thermostable EC 3.2.1.8 xylanase preparation produced by a strain of non-pathogenic fungi and specially designed to improve the bleachability of woody kraft pulps at high temperature. The xylanase activity of the product was standardized by the supplier to $190,000 \mathrm{TXU} \mathrm{g}^{-1}$. One thermoxylanase unit (TXU) is defined as the amount of enzyme that produces reducing carbohydrates with a reducing power corresponding to one nanomole of xylose from birch xylan in one second under assay conditions. The DNS-xylanase assay was used to determine xylanase activity in citrate phosphate buffer at pH 7 [11]. Pulpzyme ${ }^{\circledR}$ HC is an EC 3.2.1.8 xylanase activity produced by submerged fermentation of a genetically modified Bacillus microorganism. The product was standardized to $1000 \mathrm{AXU} \mathrm{g}^{-1}$ (xylanase unit). One xylanase unit was defined as the amount of enzyme which under standard conditions ( $\mathrm{pH} 9.0,50{ }^{\circ} \mathrm{C}, 30 \mathrm{~min}$ incubation) releases a defined amount of dye from dyed xylan (remazol-stained wheat arabinoxylan) [12].

All other chemical reagents were of analytical grade and purchased from Sigma-Aldrich, Fluka and Riedel-de-Haen companies.

\subsection{Xylanase pre-treatment}

The enzymatic pulp pre-treatment was performed under conditions recommended by suppliers (Table 1). $30 \mathrm{~g}$ (on oven-dry basis) of unbleached kraft pulp was thoroughly hand mixed with the xylanase solution $\left(76 \mathrm{TXU} \mathrm{g}^{-1}\right.$ of Ecopulp ${ }^{\circledR}$ or $1 \mathrm{AXU} \mathrm{g}^{-1}$ of Pulpzyme ${ }^{\circledR}$ ) at $10 \%$ consistency and $\mathrm{pH} 7$ in the double-layer plastic bags and incubated in a water bath for $3 \mathrm{~h}$ at the required temperature of $65^{\circ} \mathrm{C}$ or $60^{\circ} \mathrm{C}$ (for Ecopulp ${ }^{\circledR}$ and Pulpzyme ${ }^{\circledR}$, respectively). After an enzymatic hydrolysis, the pulps were carefully washed with deionised water. The reference (control) samples were treated by exactly the same way, but without enzyme addition. Two replicate enzymatic as well as control treatments were performed for each xylanase preparation.

\subsection{Peroxide bleaching}

The xylanase pre-treated and control pulps were bleached by three-stage hydrogen peroxide sequence, without oxygen predelignification. For reason of process uniformity, the specific bleaching conditions (time, temperature and chemical charge) were kept the same for each peroxide stage (Table 1). The pulp chelating with ethylenediaminetetraacetic acid (EDTA) was done before bleaching to remove the transition metals and therefore to prevent the peroxide decomposition. Epsom salt (magnesium sulfate) and DTPA (diethylenetriaminepentaacetic acid) were also used during peroxide bleaching to minimize the radical-induced degradation reactions of carbohydrates. Peroxide bleaching as well as pulp chelating were performed in the sealed plastic bags plunged into an agitated water bath with controlled heating. After bleaching, the pulps were thoroughly washed by deionized water.

Table 1

Bleaching conditions

\begin{tabular}{|c|c|c|c|c|}
\hline & $X\left(\right.$ Ecopulp $\left.^{\circledR}\right)$ & X (Pulpzyme $\left.{ }^{\circledR}\right)$ & Q-stage & P-stage \\
\hline Pulp consistency $(\%)$ & 10 & 10 & 3 & 10 \\
\hline Temperature $\left({ }^{\circ} \mathrm{C}\right)$ & 65 & 60 & 70 & 90 \\
\hline Time (min) & 180 & 180 & 60 & 180 \\
\hline Enzyme dosage $\left(\mathrm{XU} \mathrm{g}^{-1}\right)$ & $76^{\mathrm{a}}$ & $1^{\mathrm{b}}$ & - & - \\
\hline $\mathrm{H}_{2} \mathrm{O}_{2}$ charge (\% oven-dry pulp) & - & - & - & 3.0 \\
\hline $\mathrm{NaOH}$ charge (\% oven-dry pulp) & - & - & - & 1.5 \\
\hline EDTA charge ( $\%$ oven-dry pulp) & - & - & 0.3 & - \\
\hline DTPA charge (\% oven-dry pulp) & - & - & - & 0.2 \\
\hline $\mathrm{MgSO}_{4}$ charge (\% oven-dry pulp) & - & - & - & $0.3^{\mathrm{c}}$ \\
\hline $\mathrm{pH}$ initial & 7.0 & 7.0 & $4.5^{\mathrm{d}}$ & - \\
\hline $\mathrm{pH}$ final & - & - & - & $10.1-10.4^{\mathrm{e}}$ \\
\hline
\end{tabular}

\footnotetext{
a TXU per gram of oven-dry pulp.

b AXU per gram of oven-dry pulp.

c Magnesium sulfate was applied as $\mathrm{MgSO}_{4} \cdot 7 \mathrm{H}_{2} \mathrm{O}$.

${ }^{\mathrm{d}} \mathrm{pH}$ was adjusted by diluted sulfuric acid.

e $\mathrm{pH}$ value varies with stage and pulp sample.
} 
Two replicate bleaching experiments were performed for each enzyme-treated and control pulp.

\subsection{Pulp analysis}

Residual lignin content was determined as a Klason and acid-soluble lignin according to T $222 \mathrm{om}-88$ and UM 250 TAPPI standards. Pulp viscosity was measured in cupriethylenediamine (CED) solution according to SCAN-CM 15:88 standard. Handsheet formation for physical and reflectance tests of pulps were performed according to TAPPI T 205 om- 88 and TAPPI T 272 om- 92 standards, respectively. Papermaking properties of pulp handsheets were examined according to TAPPI T 220 om-88 standard. Pulp optical properties, i.e., ISO brightness and DIN $6167 \mathrm{C} / 2$ yellowness index, were measured by CM-3630 Spectrophotometer (Minolta).

Carbohydrate composition was determined by GC of the alditol-acetate derivatives of monosaccharides after pulp Saeman hydrolysis [13], as described elsewhere [14].

Hexenuronic acid groups in pulps were quantified by selective hydrolysis in formic acid-sodium formate buffer followed by UV-spectroscopy (Shimadzu, UV-160A) of the formed 2furoic acid at $245 \mathrm{~nm}$ [15]. The degree of association between analytical data on HexA removal and brightness improvement during bleaching was checked using statistical software SPSS 13.0 for Windows and expressed as the Pearson's correlation coefficient $(R)$ at the significance level $(p)$.

At least three replicate analyses were performed in all cases.

\section{Results and discussion}

To assess the effect of xylanases on peroxide bleachability of E. globulus kraft pulp, the unbleached industrial euca- lypt kraft pulp was treated with two commercial xylanase preparations Ecopulp ${ }^{\circledR}$ TX-200A and Pulpzyme ${ }^{\circledR}$ HC (endo$1,4-\beta$-xylanase activity; EC 3.2.1.8) and bleached by totally chlorine-free (TCF) three-stage hydrogen peroxide bleaching sequence (QPPP, where $\mathrm{Q}$ is a pulp chelating and $\mathrm{P}$ is a hydrogen peroxide bleaching stage), without oxygen pre-delignification. The change in pulp properties after each bleaching stage has been examined and compared with control samples, processed by exactly the same way but without enzyme addition.

The hydrogen peroxide bleaching was chosen as a simple to performance, effective and fairly selective chlorine-free process, which is generally used as a separate bleaching stage incorporated into the multi-stage bleaching sequence for successful bleaching of industrial pulps. The use of three peroxide stages intended to achieve the maximum bleaching effect of peroxide with tested pulps.

\subsection{Direct bleaching effect}

As would be expected from the known mode of xylanase performance during pulp biobleaching, the direct brightening and delignification was already observed immediately after the enzymatic stage (X-stage), i.e., before chemical bleaching. The gain in brightness of 1.5 and $1.2 \%$ ISO as well as the lignin removal by 10.5 and $6.9 \%$ (as compared with control) was noted respectively for Ecopulp ${ }^{\circledR}{ }_{-}$and Pulpzyme ${ }^{\circledR}$-treated E. globulus kraft pulps (Table 2). The brightness stability (reverted brightness) and, particularly, intrinsic viscosity of xylanase-treated pulps was also found superior to control.

The similar direct bleaching effect has been reported for some other pulps [16-18] and was attributed to an enzymatic attack of LCC with removal of some lignin fragments and lignin-

Table 2

Results of xylanase-aided three-stage hydrogen peroxide bleaching of E. globulus kraft pulp (X, enzymatic pre-treatment; Q, chelating; P, peroxide bleaching stage)

\begin{tabular}{|c|c|c|c|c|c|c|c|c|}
\hline \multirow[t]{2}{*}{ Ecopulp $^{\circledR}$} & \multicolumn{2}{|l|}{$\mathrm{X}$} & \multicolumn{2}{|l|}{$\mathrm{XQP}$} & \multicolumn{2}{|l|}{ XQPP } & \multicolumn{2}{|l|}{ XQPPP } \\
\hline & Control & Enzyme & Control & Enzyme & Control & Enzyme & Control & Enzyme \\
\hline Brightness (\% ISO) & 42.4 & 43.9 & 75.8 & 77.9 & 81.2 & 82.9 & 85.0 & 86.4 \\
\hline Yellowness index & 33.9 & 32.3 & 11.9 & 9.9 & 6.0 & 5.3 & 2.7 & 2.1 \\
\hline Reverted brightness (\% ISO) $^{\mathrm{a}}$ & 41.5 & 43.2 & 74.7 & 76.7 & 80.4 & 82.1 & 83.6 & 84.6 \\
\hline Lignin (\% on oven-dry pulp) & 3.33 & 2.98 & 1.95 & 1.57 & 1.63 & 1.24 & 1.40 & 1.03 \\
\hline Klason lignin & 1.96 & 1.73 & 0.71 & 0.50 & 0.55 & 0.30 & 0.39 & 0.15 \\
\hline Acid-soluble lignin & 1.37 & 1.25 & 1.24 & 1.07 & 1.08 & 0.94 & 1.01 & 0.88 \\
\hline Intrinsic viscosity $\left(\mathrm{mL} \mathrm{g}^{-1}\right)$ & 1357 & 1384 & 1111 & 1194 & 1056 & 1144 & 826 & 789 \\
\hline \multirow[t]{2}{*}{ Pulpzyme $^{\circledR}$} & \multicolumn{2}{|l|}{$\mathrm{X}$} & \multicolumn{2}{|l|}{$\mathrm{XQP}$} & \multicolumn{2}{|l|}{ XQPP } & \multicolumn{2}{|l|}{ XQPPP } \\
\hline & Control & Enzyme & Control & Enzyme & Control & Enzyme & Control & Enzyme \\
\hline Brightness (\% ISO) & 42.0 & 43.2 & 74.8 & 76.9 & 80.1 & 81.5 & 84.5 & 85.7 \\
\hline Yellowness index & 34.2 & 33.0 & 12.8 & 10.9 & 6.5 & 5.9 & 2.9 & 2.3 \\
\hline Reverted brightness (\% ISO) $^{\mathrm{a}}$ & 40.9 & 42.3 & 73.6 & 75.6 & 79.2 & 80.6 & 84.4 & 83.1 \\
\hline Lignin (\% on oven-dry pulp) & 3.06 & 2.85 & 1.87 & 1.60 & 1.61 & 1.30 & 1.29 & 1.03 \\
\hline Klason lignin & 1.72 & 1.55 & 0.55 & 0.41 & 0.41 & 0.21 & 0.31 & 0.13 \\
\hline Acid-soluble lignin & 1.34 & 1.30 & 1.32 & 1.19 & 1.20 & 1.09 & 0.98 & 0.90 \\
\hline Intrinsic viscosity $\left(\mathrm{mL} \mathrm{g}^{-1}\right)$ & 1357 & 1375 & 1119 & 1135 & 945 & 959 & 719 & 661 \\
\hline
\end{tabular}

The data on two xylanase preparations are presented.

${ }^{\text {a }}$ Measured after keeping of pulps at $105^{\circ} \mathrm{C}$ for $4 \mathrm{~h}$ followed by $2 \mathrm{~h}$ at room temperature in a dark box. 
associated chromophores $[19,20]$. The enzyme-assisted removal of xylan-derived chromophores (e.g., hexenuronic acids) with dissolved xylooligosaccharide fractions [18] can also contribute to brightness as well as brightness stability improvement [21]. The dissolution of low-molecular weight (oligosaccharide) xylan fractions is an obvious reason for elevated pulp viscosity of enzyme-treated pulps $[6,16]$.

\subsection{Bleach boosting}

The effect of xylanases on pulp bleaching (i.e., bleach boosting effect) is normally assessed through examination of brightness improvement of fully bleached pulps. No reported data is available about the fate of this effect along the bleaching progress. At the same time, our study showed that the bleach boosting differs for each bleaching stage and varies substantially within the bleaching sequence. Thus, the brightness improvement after complete bleaching not always reflects the actual effectiveness of the applied xylanases, although the final brightness of bleached pulps is undoubtedly the property of main interest and importance.

As can be seen from Table 2, in the three-stage hydrogen peroxide bleaching sequence the maximal xylanase bleach boosting is achieved after the first peroxide stage, with equal brightness improvement by $2.1 \%$ ISO (in comparison with control) for both tested xylanase preparations. The positive effect of xylanases was then substantially diminished in the two subsequent peroxide stages. The gain in brightness by 1.4 and $1.2 \%$ ISO only (respectively for Ecopulp ${ }^{\circledR}$ - and Pulpzyme ${ }^{\circledR}$-treated pulps) was noted after complete bleaching, what was even less of that achieved through the direct brightening after the enzymatic stage. The negative impact of consecutive hydrogen peroxide stages on brightness improvement was also noted for some other mixed hardwood and pine kraft pulps treated by fungus xylanase preparation [17].

The reduced gain in brightness at the end of bleaching cannot be explained by change (or fall) in lignin removal of enzymetreated pulps. It is evident from the presented data (Table 2) that both xylanases enhance pulp delignification during each peroxide stage causing additional lignin loss by about $11 \%$ and
9\% (for Ecopulp ${ }^{\circledR}$ - and Pulpzyme ${ }^{\circledR}$-treated pulps, respectively) in comparison with control. Thus, it is most likely that the polysaccharide-derived chromophores of eucalypt kraft pulps are responsible for the loss in xylanase efficiency during peroxide bleaching.

\subsection{Pulp bleachability}

The efficiency of active bleaching chemical (hydrogen peroxide) to improve pulp brightness and degree of delignification during bleaching can be assumed as a measure of relative pulp bleachability. In Fig. 1, the calculated values of lignin removal and brightness improvement of enzyme-treated and control pulps are plotted versus hydrogen peroxide charge applied to each bleaching stage. It is evident that in terms of lignin removal, the bleachability of xylanase-treated pulps on each stage of bleaching sequence is substantially higher in comparison with control. The lignin removal by $65.4 \%$ and $63.7 \%$ vs. $58.0 \%$ and $57.9 \%$ was noted for enzyme-treated (Ecopulp ${ }^{\circledR}$ and Pulpzyme ${ }^{\circledR}$-treated, respectively) and corresponding control pulps, within the specified range of peroxide charge of 3-9\%.

In terms of brightness improvement, in spite of generally higher final brightness of enzyme-treated pulps, the bleachability of these pulps was superior to control only during the first two peroxide stages, under peroxide charge of $3 \%$ and $6 \%$ (Fig. 1, right). No bleachability improvement over the control was noted during the last peroxide stage (i.e., the same increase in brightness for treated and control pulps by about $42.5 \%$ ISO for both xylanase preparations), as a result of diminished xylanase bleach boosting effect discussed in the previous chapter.

\subsection{Bleaching selectivity}

The pulp viscosity is a basic and one of the most important pulp properties that makes it possible to check the extent of carbohydrate degradation caused by pulping and bleaching and to predict thereby the quality (first of all the strength properties) of final fiber products. The change in pulp viscosity with brightness development and lignin removal defines the selec-
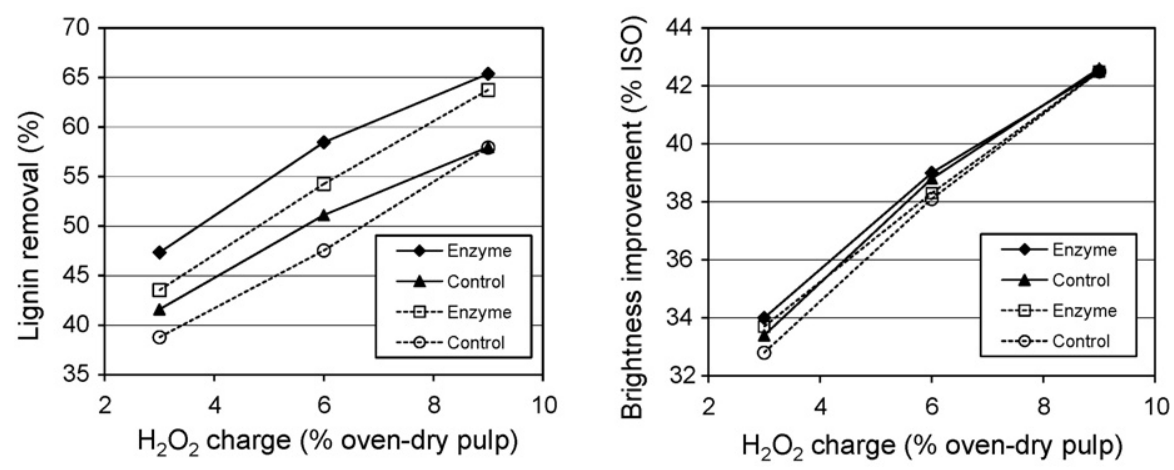

Fig. 1. Residual lignin removal (left) and brightness improvement (right) of xylanase-treated (Ecopulp ${ }^{\circledR}$ —solid line and Pulpzyme ${ }^{\circledR}$-dash line) and corresponding control (untreated) E. globulus kraft pulps during XQPPP bleaching (where X, xylanase treatment; Q, pulp chelating; P, hydrogen peroxide stage) vs. hydrogen peroxide charge applied to each bleaching stage. 

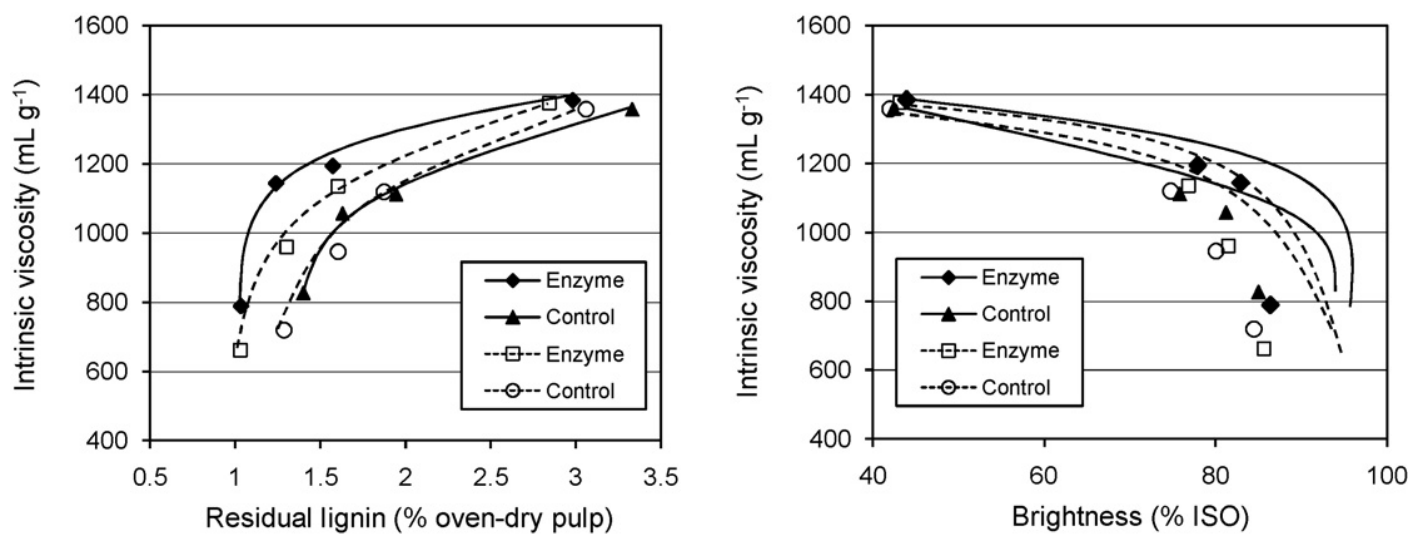

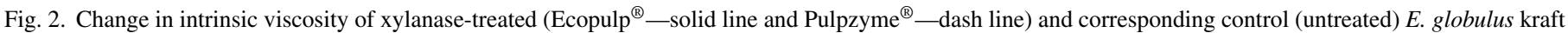

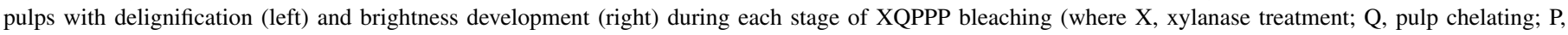
hydrogen peroxide stage).

tivity of bleaching process with respect to the main bleaching objectives-brightening and delignification [22].

In Fig. 2, the intrinsic viscosity of enzyme-treated and control pulps, measured after each bleaching stage, is shown as a function of residual lignin content and pulp brightness, respectively. Obviously, the xylanases substantially improve the peroxide bleaching selectivity of E. globulus kraft pulp. In the selected range of residual lignin content of 1.4-3.0\% and pulp brightness of 44-85\% ISO, the intrinsic viscosity of both the Ecopulp ${ }^{\circledR}$ - and Pulpzyme $^{\circledR}$-treated pulps is always higher in comparison with control.

At the same time, the dramatic drop in viscosity (over the control) of both enzyme-treated pulps was observed after more profound bleaching (ca. 1\% lignin and ca. $86 \%$ ISO brightness, Fig. 2) at the end of the last peroxide stage, giving thereby the final viscosity values of fully bleached enzyme-treated pulps somewhat inferior to those of control (Table 2). Thus, the positive effect of xylanase treatment on pulp viscosity shown after an enzymatic and the first two chemical bleaching stages is lost by the end of complete bleaching. The enhanced degradation of lignin-associated carbohydrates and cellulose under deep delignification of enzyme-treated pulps within the last peroxide stage caused the noted decrease in pulp viscosity.

\subsection{Carbohydrate degradation}

The principal non-cellulosic polysaccharide of E. globulus $\mathrm{L}$. wood is a branched heteroxylan (2-O- $\alpha$-D-galactopyranosyl$4-O$-methyl- $\alpha$-D-glucurono)-D-xylan composed of galactosyl, 4-O-methyl-glucuronosyl and xylosyl residues with molar ratio

Table 3

Change in carbohydrate composition of E. globulus kraft pulp during xylanase-aided three-stage hydrogen peroxide bleaching (X, enzymatic pre-treatment; Q, chelating; P, peroxide bleaching stage)

\begin{tabular}{|c|c|c|c|c|c|c|c|c|}
\hline \multirow[t]{2}{*}{ Ecopulp $^{\circledR}$ (neutral sugar composition, \% dry pulp) } & \multicolumn{2}{|l|}{$\mathrm{X}$} & \multicolumn{2}{|l|}{$\mathrm{XQP}$} & \multicolumn{2}{|l|}{$\mathrm{XQPP}$} & \multicolumn{2}{|l|}{ XQPPP } \\
\hline & Control & Enzyme & Control & Enzyme & Control & Enzyme & Control & Enzyme \\
\hline Rhamnose & 0.022 & 0.020 & 0.016 & 0.014 & 0.014 & 0.015 & 0.019 & 0.018 \\
\hline Fucose & 0.008 & 0.007 & 0.011 & 0.005 & 0.006 & 0.006 & 0.005 & 0.005 \\
\hline Arabinose & 0.441 & 0.451 & 0.351 & 0.349 & 0.324 & 0.302 & 0.292 & 0.230 \\
\hline Xylose & 17.103 & 15.557 & 16.407 & 14.402 & 15.819 & 13.608 & 15.336 & 12.975 \\
\hline Mannose & 0.188 & 0.188 & 0.186 & 0.181 & 0.167 & 0.175 & 0.161 & 0.156 \\
\hline Galactose & 0.326 & 0.276 & 0.295 & 0.222 & 0.264 & 0.210 & 0.254 & 0.196 \\
\hline Glucose & 82.552 & 82.372 & 82.049 & 81.881 & 81.568 & 80.789 & 80.935 & 80.011 \\
\hline HexA ( $\mu \mathrm{mol} \mathrm{g}^{-1}$ dry pulp) & 50.45 & 43.13 & 44.13 & 34.69 & 39.81 & 32.19 & 36.60 & 30.63 \\
\hline \multirow[t]{2}{*}{ Pulpzyme $^{\circledR}($ Neutral sugar composition, \% dry pulp) } & \multicolumn{2}{|l|}{$\mathrm{X}$} & \multicolumn{2}{|l|}{$\mathrm{XQP}$} & \multicolumn{2}{|l|}{ XQPP } & \multicolumn{2}{|l|}{ XQPPP } \\
\hline & Control & Enzyme & Control & Enzyme & Control & Enzyme & Control & Enzyme \\
\hline Rhamnose & 0.031 & 0.023 & 0.027 & 0.026 & 0.015 & 0.015 & 0.013 & 0.011 \\
\hline Fucose & 0.015 & 0.006 & 0.009 & 0.006 & 0.005 & 0.007 & 0.005 & 0.005 \\
\hline Arabinose & 0.409 & 0.442 & 0.385 & 0.415 & 0.361 & 0.365 & 0.269 & 0.225 \\
\hline Xylose & 16.781 & 15.802 & 16.113 & 14.994 & 15.586 & 14.056 & 15.098 & 13.348 \\
\hline Mannose & 0.196 & 0.202 & 0.189 & 0.210 & 0.152 & 0.174 & 0.145 & 0.150 \\
\hline Galactose & 0.316 & 0.263 & 0.273 & 0.231 & 0.231 & 0.207 & 0.220 & 0.183 \\
\hline Glucose & 82.497 & 82.445 & 82.013 & 81.916 & 81.836 & 81.495 & 80.972 & 80.619 \\
\hline HexA ( $\mu \mathrm{mol} \mathrm{g}^{-1}$ dry pulp) & 49.16 & 43.69 & 44.04 & 35.92 & 40.19 & 33.77 & 37.14 & 31.88 \\
\hline
\end{tabular}




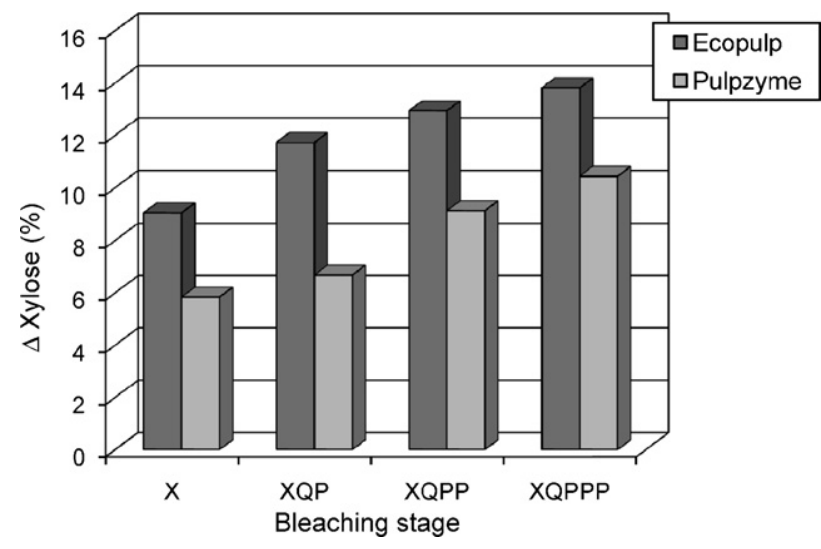

Fig. 3. Effect of xylanase treatment on relative (over the control) xylose (or xylan) removal from E. globulus kraft pulps during each stage of XQPPP bleaching (where $\mathrm{X}$, xylanase treatment; $\mathrm{Q}$, pulp chelating; $\mathrm{P}$, hydrogen peroxide stage).

of 1:3:30 and comprised about $20.8 \%$ of total carbohydrates [23,24]. During kraft pulping the structure of heteroxylan is substantially modified. The intensive chain scission with elimination of side-chains reduces the average molecular weight of polysaccharide in kraft pulp from 25,600 to 13,700 and gives the new molar ratio of monosaccharide residues of about 1:4:70 [25].

As can be seen from Table 3, the enzymatic hydrolysis of $E$. globulus kraft pulp leads to exclusive removal of heteroxylanderived monosaccharide residues, i.e., xylose and galactose, confirming the high selectivity of the used xylanase preparation and essential purity from other enzymatic (particularly cellulase) activities.

The change in xylose content, as a main polysaccharide constituent, generally reflects the bleaching behavior of the heteroxylan as a whole. The enzymatic effect on xylose removal during three-stage peroxide bleaching is shown in Fig. 3. It is evident that xylanase pre-treatment with Ecopulp ${ }^{\circledR}$ is more effective and dissolves about $9 \%$ of xylan vs. $5.8 \%$ - for Pulpzyme ${ }^{\circledR}$. Both xylanase preparations cause additional xylan removal (over the control pulps) with each subsequent peroxide bleaching stage, as an obvious result of facilitated polysaccharide accessibility to degradation by active oxidation chemicals in bleaching solution.

No apparent correlation was observed between enzymeassisted removal (over the control) of neutral carbohydrates (particularly xylan) and the gain in brightness and delignification achieved during peroxide bleaching. A similar observation was also reported for peroxide bleaching of xylanase-treated softwood pulps [26].

\subsection{Hexenuronic acid profile}

In alkaline pulps, about 75-90\% of 4-O-methyl-glucuronic acid side groups (MeGlcA) linked to heteroxylan are lost during pulping, and the residual MeGlcA are almost completely (by $83-88 \%$ ) converted to unsaturated moiety hexenuronic acid (HexA or 4-deoxy- $\beta$-L-threo-hex-4-enopyranosyluronic acid) by $\beta$-elimination of methanol via the intermediate product 4-O-methyliduronic acid $[27,28]$. The HexA have significant

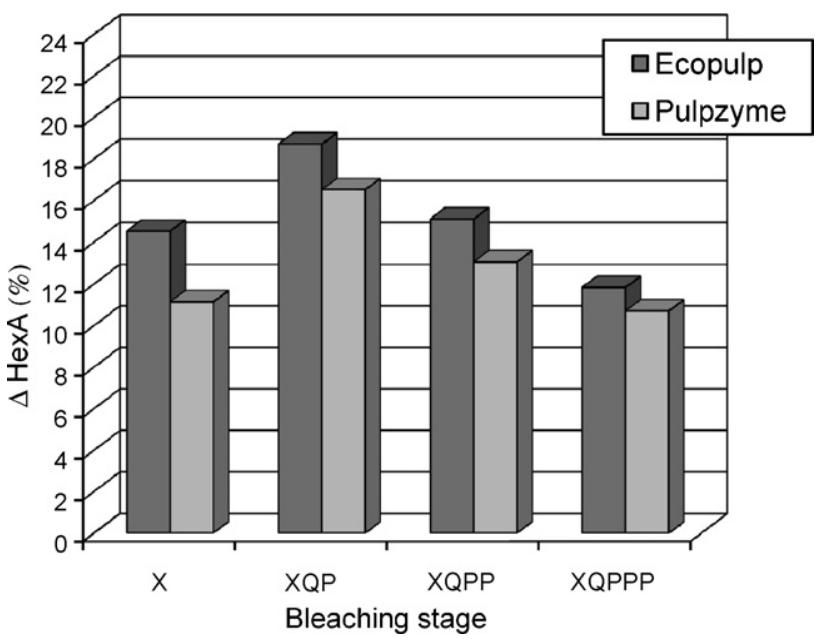

Fig. 4. Effect of xylanase treatment on relative (over the control) hexenuronic acids (HexA) removal from E. globulus kraft pulps during each stage of XQPPP bleaching (where X, xylanase treatment; $Q$, pulp chelating; $P$, hydrogen peroxide stage).

detrimental effect on the following pulp bleaching causing increased consumption of bleaching chemicals, decreased pulp brightness and increased brightness reversion [15,21].

The fate of HexA during xylanase-aided three-stage peroxide bleaching of E. globulus kraft pulp is shown in Table 3 and Fig. 4. As evident, the HexA content was substantially reduced after enzymatic treatment with both xylanase preparations (by $14.5 \%$ and $11.1 \%$ for Ecopulp ${ }^{\circledR}$ and Pulpzyme ${ }^{\circledR}$, respectively). It was shown elsewhere that all HexA losses on this stage result from enzymatic solubilization of HexA-carrying xylooligosaccharide fractions, i.e., aldohexenuronic acids with degree of polymerisation from 5 to 8 [18]. The more effective HexA removal from Ecopulp ${ }^{\circledR}$-treated pulps correlates well with data on xylan removal and, along with better direct delignification, is a most probable reason of higher direct brightness and brightness stability of these pulps in comparison with Pulpzyme ${ }^{\circledR}$-treated ones.

As could be expected from data on xylan degradation, the additional (over the control) HexA removal was observed during the following peroxide bleaching of xylanase-treated pulps. However, in contrast to xylan, the maximum of HexA losses $\left(18.7 \%\right.$ and $16.5 \%$, respectively for Ecopulp ${ }^{\circledR}{ }_{-}$and Pulpzyme ${ }^{\circledR}$-treated pulps) were observed after the first peroxide stage with progressive decrease in HexA losses with bleaching extension (Fig. 4). It is obvious that the HexA behavior during xylanase-aided peroxide bleaching closely matches the specificity of bleach boosting effect (or xylanase-assisted gain in brightness) observed in this study. In Fig. 5, the values of gain in brightness for both Ecopulp ${ }^{\circledR}{ }_{-}$and Pulpzyme ${ }^{\circledR}$ treated pulps achieved after each bleaching stage (including $\mathrm{X}$-stage) are plotted versus corresponding values of HexA losses. Correlation analysis using Statistical Package SPSS 13.0 showed a strong positive correlation between these data sets with the correlation coefficient (Pearson's coefficient) $R=0.954$ at the significance level $p=0.01$. Considering a fairly moderate difference in rate of delignification between enzymetreated and control pulps at the end of bleaching, the HexA removal during xylanase-aided peroxide bleaching of E. glob- 
Table 4

Physical properties of xylanase pre-treated fully bleached unbeaten E. globulus kraft pulps, as compared with control (untreated) pulps

\begin{tabular}{|c|c|c|c|c|c|c|c|}
\hline & \multicolumn{3}{|c|}{ Ecopulp $^{\circledR}$} & \multicolumn{3}{|c|}{ Pulpzyme $^{\circledR}$} & \multirow[t]{2}{*}{ Initial pulp ${ }^{a}$} \\
\hline & Enzyme & Control & $\Delta(\%)^{\mathrm{b}}$ & Enzyme & Control & $\Delta(\%)$ & \\
\hline Burst index $\left(\mathrm{kPa} \mathrm{m}^{2} \mathrm{~g}^{-1}\right)$ & 0.37 & 0.62 & 40.3 & 0.40 & 0.59 & 32.2 & 0.41 \\
\hline Tensile index $\left(\mathrm{N} \mathrm{mg}^{-1}\right)$ & 8.67 & 11.60 & 25.3 & 8.98 & 10.13 & 11.4 & 10.49 \\
\hline Tear index $\left(\mathrm{mN} \mathrm{m}^{2} \mathrm{~g}^{-1}\right)$ & 4.08 & 4.55 & 10.3 & 4.26 & 4.64 & 8.2 & 4.40 \\
\hline Bulk $\left(\mathrm{cm}^{3} \mathrm{~g}^{-1}\right)$ & 2.02 & 2.01 & 0.5 & 2.00 & 1.94 & 3.0 & 1.97 \\
\hline
\end{tabular}

a Unbleached kraft pulp before enzymatic treatment.

b Property loss, \%.

ulus kraft pulp seems to be the controlling factor in definition of final brightness of fully bleached pulps, as it was suggested above.

\subsection{Physical properties}

Hemicelluloses improve the inter-fibrillar bonding during paper-sheet formation and have thereby favorable effect of mechanical (physical) properties of papermaking fibers [29]. It might be highly expected therefore, that xylan removal during enzymatic stage will impair the strength of treated pulps in comparison with untreated ones. The physical properties of fully bleached unbeaten E. globulus kraft pulps are shown in Table 4. As evident, the pulp strength was adversely affected by the enzymatic treatment with both (Ecopulp ${ }^{\circledR}$ and Pulpzyme ${ }^{\circledR}$ ) xylanase preparations. The loss in bursting and tensile strength (by $32-40 \%$ and $11-25 \%$, respectively) was more notable in comparison with tear strength (8.2-10.3\%), confirming the previous observations [30]. The difference in strength properties (particularly in tear) between bleached enzyme-treated and untreated (control) pulps is normally minimized after pulp refining [26,31], as a possible result of greater external fibrillation of treated pulp after enzymatic elimination of re-deposited xylan on the surface of the fibers [31]. Nevertheless, the physical properties of xylanase-treated peroxide bleached eucalypt pulps

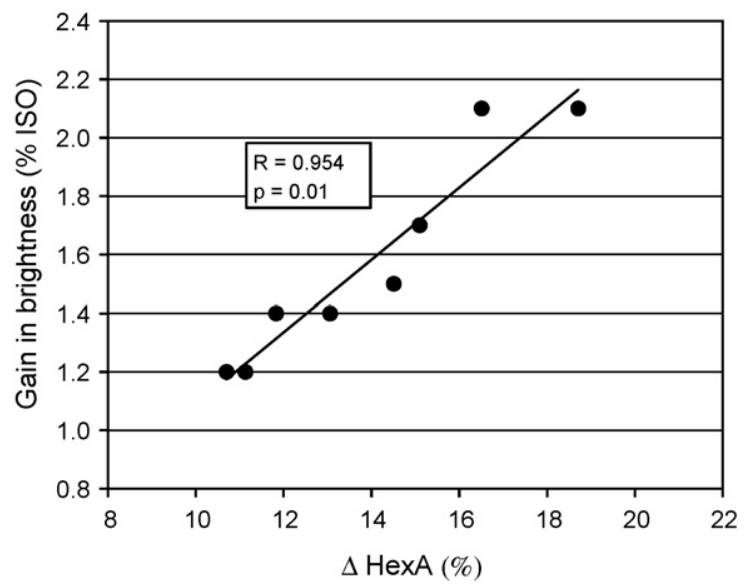

Fig. 5. Correlation between gain in brightness (over the control) of xylanasetreated (both Ecopulp ${ }^{\circledR}$ and Pulpzyme ${ }^{\circledR}$ ) E. globulus kraft pulps and relative (over the control) hexenuronic acids (HexA) removal $(R$, Pearson's correlation coefficient; $p$, significance level) during each stage of XQPPP bleaching (where $\mathrm{X}$, xylanase treatment; $\mathrm{Q}$, pulp chelating; $\mathrm{P}$, hydrogen peroxide stage). are very close to those of initial unbleached pulps (Table 4), suggesting only limited carbohydrate degradation during entire bleaching.

\section{Conclusions}

The beneficial effect of commercial xylanases on bleachability of eucalypt (E. globulus L.) kraft pulp was shown to be limited when enzymatic pre-treatment was combined with extended (three-stage) hydrogen peroxide bleaching sequence (without oxygen pre-delignification). In spite of a generally higher bleachability and bleaching selectivity of xylanasetreated pulps, the maximal gain in pulp brightness (or bleach boosting, as a main objective of xylanase application) could be achieved only after the first peroxide bleaching stage and then substantially diminished by the end of the sequence. The final gain in brightness of fully bleached pulps was close to that achieved by direct brightening during an enzymatic stage, i.e., before chemical bleaching properly. At the same time, the progressive increase in delignification of enzyme-treated pulps through bleaching was also noted. A strong correlation between the remarkable loss in brightness improvement of enzyme-treated pulps and the bleaching profile of hexenuronic acids underlined the critical importance of carbohydrate-derived chromophores in definition of final brightness of fully bleached pulps and pointed to HexA as one of the principal factors affecting bleaching efficiency of xylanase treatment.

\section{Acknowledgments}

The financial support of the Fundação para a Ciência e a Tecnologia (FCT, Portugal) within research contract SFRH/BPD/9376/2002 is gratefully acknowledged. The authors thank Mr. Pasi Taipalus (AB Enzymes, Finland) and Mr. Eugen Muller (Novozymes Deutschland $\mathrm{GmbH}$ ) for providing enzymes.

\section{References}

[1] L. Viikari, A. Kantelinen, J. Sundquist, M. Linko, Xylanases in bleaching: from an idea to the industry, FEMS Microbiol. Rev. 13 (1994) 335350 .

[2] A. Suurnakki, M. Tenkanen, J. Buchert, L. Viikari, Hemicellulases in the bleaching of chemical pulps, in: K. Eriksson (Ed.), Biotechnology in the Pulp and Paper Industry, Springer-Verlag, Berlin, 1997, pp. 261-287. 
[3] J.S. Tolan, D. Olson, R.E. Dines, Survey of mill usage of xylanase, in: T.W. Jeffries, L. Viikari (Eds.), Enzymes for Pulp and Paper Processing, ACS Symposium Series, vol. 655, 1996, pp. 25-35.

[4] R.W. Allison, T.A. Clark, Effect of enzyme pre-treatment on ozone bleaching, Tappi J. 77 (1994) 127-134.

[5] P. Bajpai, P.K. Bajpai, Microbial xylananolytic enzyme system, in: S. Nidelman, A. Laskin (Eds.), Advances in Applied Microbiology, vol. 43, Academic Press, New York, 1997, pp. 141-194.

[6] A. Kantelinen, B. Hortling, J. Sundquist, M. Linko, L. Viikari, Proposed mechanism of the enzymatic bleaching of kraft pulp with xylanases, Holzforschung 47 (1993) 318-324.

[7] M.G. Paice, N. Gurnagul, D.H. Page, L. Jurasek, Mechanism of hemicellulase directed prebleaching of kraft pulp, Enz. Microb. Technol. 14 (1992) $272-276$.

[8] Z.-H. Jiang, B. Van Lierop, R. Berry, Hexenuronic acid groups in pulping and bleaching chemistry, Tappi J. 83 (2000) 167-175.

[9] J. Soares, in: J.S. Pereira, H. Pereira (Eds.), Eucalypts for pulp production, EC, 1994, pp. 283-286.

[10] Boletim Estatístico, CELPA, Associação da Indústria Papeleira, 2005, pp. 32-35.

[11] M.J. Bailey, P. Biely, K. Poutanen, Interlaboratory testing of methods for assay of xylanase activity, J. Biotechnol. 23 (1992) 257-270.

[12] Novozymes A/S standard method, SOP No.: EB-SM-0408.02/02.

[13] J.F. Saeman, W.E. Moore, M.A. Millet, in: R.L. Whistler (Ed.), Methods in Carbohydrate Chemistry, Academic Press, New York, 1963, pp. 54-69.

[14] A.A. Shatalov, H. Pereira, Polysaccharide degradation during ozone based TCF bleaching of non-wood organosolv pulps, Carbohydr. Polym. 67 (2007) 275-281.

[15] T. Vuorinen, P. Fagerström, J. Buchert, M. Tenkanen, A. Teleman, Selective hydrolysis of hexenuronic acid groups and its application in ECF and TCF bleaching of kraft pulps, J. Pulp Paper Sci. 25 (1999) J155-J162.

[16] A. Suurnakki, A. Kantelinen, J. Buchert, L. Viikari, Enzyme-aided bleaching of industrial softwood kraft pulps, Tappi J. 77 (1994) 111-116.

[17] J.L. Yang, G. Lou, K-E.L. Eriksson, The impact of xylanase on bleaching of kraft pulps, Tappi J. 75 (1992) 95-101.

[18] A.A. Shatalov, H. Pereira, Xylanase pre-treatment of giant reed organosolv pulps: direct bleaching effect and bleach boosting, Ind. Crops Prod. 25 (2007) 248-256.
[19] J.L. Yang, K-E.L. Eriksson, Use of hemicellulolytic enzymes as one stage in bleaching of kraft pulps, Holzforschung 46 (1992) 481-488.

[20] E. de Jong, K.K.Y. Wong, J.N. Saddler, The mechanism of xylanase prebleaching of kraft pulp: an examination using model pulps prepared by depositing lignin and xylan on cellulose fibers, Holzforschung 51 (1997) 19-26.

[21] J. Buchert, E. Bergnor, G. Lindblad, L. Viikari, M. Ek, Significance of xylan and glucomannan in the brightness reversion of kraft pulps, Tappi J. 80 (1997) 165-171.

[22] S.A. Rydholm, Pulping Processes, Interscience Publishers, New York, 1976.

[23] A.A. Shatalov, D.V. Evtuguin, C.P. Neto, (2-O- $\alpha-\mathrm{D}-$ Galactopyranosyl4-O-methyl- $\alpha$-D-glucurono)-D-xylan from Eucalyptus globulus Labill, Carbohydr. Res. 320 (1999) 93-99.

[24] A.A. Shatalov, D.V. Evtuguin, C.P. Neto, F.M.L. Amado, Unusual xylan from Eucalyptus globulus Labill, in: Proceedings of the 10th International Symposium on Wood and Pulping Chemistry (ISWPC), Yokogama, Japan, 1999, pp. 40-43.

[25] A.A. Shatalov, H. Pereira, Structure of heteroxylan from Eucalyptus globulus L. and its transformation during kraft delignification, in: Proceedings of the 20th International Carbohydrate Symposium Abstracts, Hamburg, Germany, 2000, p. 370.

[26] K.K.Y. Wong, S.L. Nelson, J.N. Saddler, Xylanase treatment for the peroxide bleaching of oxygen delignified kraft pulps derived from three softwood species, J. Biotechnol. 48 (1996) 137-145.

[27] J. Buchert, A. Teleman, V. Harjunpää, M. Tenkanen, L. Viikari, T. Vuorinen, Effect of cooking and bleaching on the structure of xylan in conventional pine kraft pulp, Tappi J. 78 (1995) 125-130.

[28] A.A. Shatalov, H. Pereira, Uronic (hexenuronic) acid profile of ethanol-alkali delignification of giant reed Arundo donax L, Cellulose 11 (2004) 109-117.

[29] J.A. Clark, Pulp Technology and Treatment for Paper, Miller Freeman Publications, San Francisco, 1981.

[30] C. Daneault, C. Leduc, J.L. Valade, The use of xylanases in kraft pulp bleaching: a review, Tappi J. 77 (1994) 125-131.

[31] M.B. Roncero, A.L. Torres, J.F. Colom, T. Vidal, The effect of xylanase on lignocellulosic components during the bleaching of wood pulps, J. Biotechnol. 96 (2005) 21-30. 